\title{
Importance of the Doctor Patient Communication to make an Adequate Diagnosis, Apropos of a Case of Endometriosis of Rare Location
}

\section{Mantinan Vivanco. $I^{1}$ and Maru Hermosa de la Llama ${ }^{2 *}$}

1Médico de Familia, Residente de tercer año, Spain

2Médico de Familia, Titular C.S.Puerto Chico, Santander,, Cantabria, Spain

*Corresponding author: Maru Hermosa de la Llama, Médico de Familia, Titular C.S.Puerto Chico, Santander,, Kantabrien, Spain, Tel: 34+699071061, E-mail: maru.hermosa@gmail.com

Received date: February 29, 2016; Accepted date: May 27, 2016; Published date: May 31, 2016

Citation: Vivanco IM, de la Llama MH (2016) Importance of the Doctor Patient Communication to make an Adequate Diagnosis, Apropos of a Case of Endometriosis of Rare Location. Reproductive Immunol Open Acc 1:13. doi: 10.21767/2476-1974.100013

Copyright: (c) 2016 Maru Hermosa de la Llama, et al. This is an open-access article distributed under the terms of the Creative Commons Attribution License, which permits unrestricted use, distribution, and reproduction in any medium, provided the original author and source are credited.

\section{Short Commentary}

The presence of focal ectopic endometrial cells (glandular and stromal cells) outside the uterine cavity is defined as endometriosis. Endometriosis is a common disease in women, whose cause is not known yet. Several theories try to explain the origin and development of this disease, being the theory named "retrograde menstruation", one of the most accepted theory. This theory, proposes that part of menstrual flow would pass through the fallopian tubes to abdominal cavity, instead of heading into the vagina through cervix. Endometrial cells would establish anywhere of abdominal cavity, giving rise to the socalled endometriotic focus. Besides of "retrograde menstruation" occurrence, which is quite more common than endometriosis in itself, probably, a kind of immunological disorder exist, that favouring the implantation and development of these foci (Figure 1) [1].

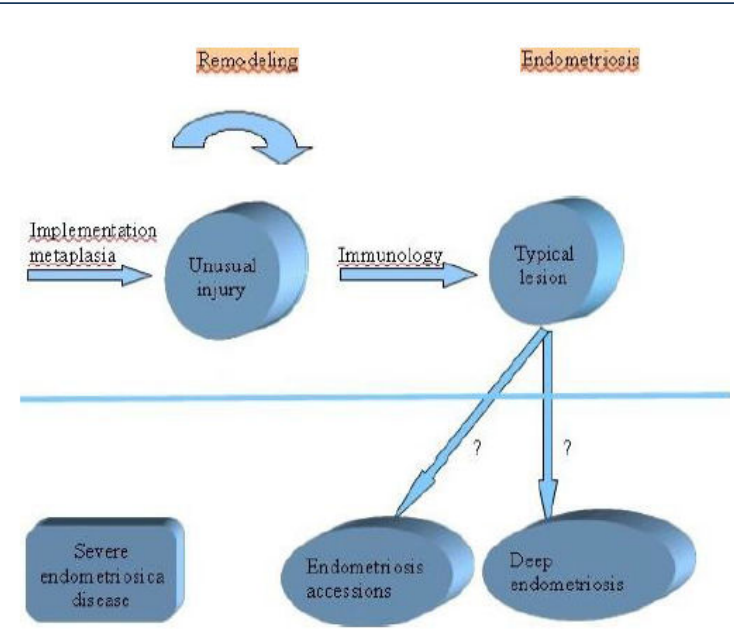

Figure 1: Etiology of endometriosis

Endometriosis is a very common disease, around a 15 percent of women in childbearing age, experiences it, those who attend to their primary care centre because of discomforts produced by the symptoms of this condition 2. Many women are asymptomatic, and the most common symptoms are shown in in table 1.

Table 1: symptoms of endometriosis

\begin{tabular}{|l|l|}
\hline Symptoms of endometriosis & $\%$ \\
\hline Depressing in $50 \%$ of the cases & $50 \%$ \\
\hline Symptomatic & $50 \%$ \\
\hline Dysmenorrhoea & $50-90 \%$ \\
\hline Dyspareunia & $25-40 \%$ \\
\hline Hypermenorrea & - \\
\hline Infertility & $30-40 \%$ \\
\hline Intestinal disorders & - \\
\hline Amenorrhea & - \\
\hline Dysfunctional bleeding & - \\
\hline
\end{tabular}

The case of a 40 yearold woman, gilt, no history, surgical or Gynaecological medical interest, that go to our inquiry by umbilical bleeding 4 days duration and spontaneous remission. The physical examination of the area is normal, no skin lesions, not seen bleeding in that moment and palpable masses are discarded. It informs the patient of what was observed, reassuring it is and he is recommended that you return if symptoms return.

A month later, it comes back with the same symptoms. In this new interview, and after a scan of the problem through a more thorough anamnesis, appears a relevant piece of information, the coincidence of bleeding with menstruation; The physical examination area shows that it is again without alterations. Before this find raises the hypothesis of endometriosis and is the derived radiology service to perform an ultrasound.

The Ultrasound in our patient study showed a dermal nodule infra umbilical compatible with the diagnosis of presumption 
which was confirmed definitively with the histopathological study part obtained after surgical treatment performed by the gynaecologist.

Thus, endometriosis can be suspected by history clinic, scanning and ultrasound techniques. Confirmation realized by histopathological studio, still the treatment surgical and pharmacological hormone combination of estrogen and progesterone $[3,4]$.

\section{References}

1. Botella Llusiá J, Clavero Núñez JA (1993) Tratado de ginecología. Enfermedades del aparato genital femenino. 14.a ed. Madrid: Editorial Díaz de Santos PP 8534.
2. Lombardia Prieto J (2007) Ginecología y Obstetricia: manual de consulta rápida. 2. a ed. Buenos Aires: Panamericana.

3. Berek y Novak. Ginecologia (2012) 15.a ed. Filadelfia: Lipincott, Williams \& Wilkins PP 505.

4. Bonilla-Musoles F, Pellicer A (2007) Obstetricia, reproducci6n y Ginecologia basicas. I.a ed. Buenos Aires: Panamericana. 